\title{
Blood parasites, total plasma protein and packed cell volume of small wild mammals trapped in three mountain ranges of the Atlantic Forest in Southeastern Brazil
}

\author{
Silva, MAML. ${ }^{\mathrm{a}}{ }^{*}$, Ronconi, A. ${ }^{\mathrm{a}}$, Cordeiro, ${ }^{\mathrm{b}}{ }^{\mathrm{b}}$, Bossi, DEP. ${ }^{\mathrm{b}}$, Bergallo, $H G .^{\mathrm{c}}$, Costa, $M C C .{ }^{\mathrm{a}}$, \\ Balieiro, JCC. ${ }^{\mathrm{a}}$ and Varzim, FLSB. ${ }^{\mathrm{a}}$ \\ ${ }^{a}$ Faculdade de Medicina Veterinária do Centro Universitário da Fundação de Ensino Octávio Bastos, \\ Av. Dr. Octávio Bastos, s/n, Campus 2, CEP 13874-159, São João da Boa Vista, SP, Brazil \\ ${ }^{b}$ Departamento de Parasitologia - Instituto de Biologia, Universidade Estadual de Campinas, \\ CP 6109, CEP 13083-970, Campinas, SP, Brazil \\ 'Departamento de Ecologia, Instituto de Biologia, Universidade do Estado do Rio de Janeiro, \\ Rua São Francisco Xavier, 524, CEP 20559-900, Rio de Janeiro, RJ, Brazil \\ *e-mail: psxerife@uol.com.br, lab1hovet@feob.br
}

Received August 5, 2005 - Accepted March 14, 2006 - Distributed August 31, 2007

\begin{abstract}
A study of blood parasites in small wild non-flying mammals was undertaken in three areas of the Atlantic Forest in Southeastern Brazil: Serra de Itatiaia, RJ, Serra da Bocaina, SP and Serra da Fartura, SP, from June 1999 to May 2001. A total of 450 animals ( 15 species) were captured in traps and it was observed in $15.5 \%$ of the blood smears the presence of Haemobartonella sp. and Babesia sp. in red blood cells. There was no statistically significant difference between parasited and non-parasited specimens regarding total plasma protein, packed cell volume and body weight, which strongly suggests that these specimens might be parasite reservoirs.
\end{abstract}

Keywords: blood parasites, wild mammals, Atlantic Forest, plasma protein, packed cell volume.

\section{Hemoparasitismo, proteína total plasmática e volume globular em pequenos mamíferos silvestres em três áreas serranas da Mata Atlântica no Sudeste do Brasil}

\section{Resumo}

A presença de hemoparasitos em pequenos mamíferos silvestres não voadores foi pesquisada em animais de três áreas serranas do Sudeste brasileiro, pertencentes ao complexo da Serra do Mar e da Serra da Mantiqueira, nos Estados de São Paulo, Rio de Janeiro e Minas Gerais. Foram capturados 420 animais de 15 espécies, durante dois anos, dos quais, 15,5\% apresentaram Haemobartonella sp. e Babesia sp., observadas em lâmina de esfregaço sangüíneo no interior de suas hemácias. Os níveis de proteína total plasmática e de volume globular não apresentaram diferença estatisticamente significativa entre os indivíduos parasitados e não parasitados, assim como o peso corporal, o que sugere fortemente que esses animais possam ser reservatórios desses parasitos.

Palavras-chave: hemoparasitos, mamíferos silvestres, Mata Atlântica, proteínas plasmáticas, volume globular.

\section{Introduction}

Domestic animals, both of economic importance and pet animals, as well as humans, are susceptible to diseases caused by blood parasites. Several blood cells parasites, such as Babesia sp, Hemobartonella sp and others, that can cause death of domestic and wild animals and, rarely, of humans, are transmitted by biological vectors such as ticks or fleas, which are ectoparasites of a wide variety of animals, and are also reservoirs of blood parasites (Daszak, Cunningham and Hyatt, 2000 and 2001; Bossi et al., 2002; Moraes, Bossi and Linhares, 2003;
Rios et al., 2003; Quintão-Silva and Ribeiro, 2003; Barreira et al., 2004).

There are several studies on the clinical, pathologic and hematologic alterations caused by hemoparasites in domestic animals, its diagnosis and transmission (Madruga et al., 2002; Mendonça et al., 2003). However, few studies have been done on hosts and reservoirs in Brazilian native species (Dall'olio et al., 2001; Gazeta et al., 2004).

This work focused on the presence of blood parasites in blood smears of small wild mammals from tropical 
mountain ranges, regarding the packed cell volume (PCV), the total plasma protein (TPP) and the body weight, determining a possible epidemiological link of important blood parasitoses in domestic and wild animals and men.

\section{Materials and Methods}

Three different areas were chosen in different mountain ranges of Southeastern Brazil: Area I- Itatiaia National Park (Itatiaia, RJ - 22 $26.187^{\prime} \mathrm{S}$ and $44^{\circ} 37.511^{\prime} \mathrm{W}$ ) between São Paulo and Rio de Janeiro states; Area IISerra da Bocaina National Park (São José do Barreiro, $\mathrm{SP}-22^{\circ} 44.125^{\prime} \mathrm{S}$ and $44^{\circ} 37.007^{\prime} \mathrm{W}$ ) between Rio de Janeiro and Minas Gerais states and Area III- Serra da Fartura (São João da Boa Vista, SP - $21^{\circ} 53.621^{\prime}$ S and $\left.46^{\circ} 45.188^{\prime} \mathrm{W}\right)$ between São Paulo and Minas Gerais states. Area I belongs to the Sea Mountain Range (Serra do Mar) and Areas II and III, to Mantiqueira Mountain Range (Serra da Mantiqueira). They all belong to the morphoclimatic domain of the mountainous regions of the humid tropics (Ab'Saber, 1970).

Small mammal trapping was conducted in an irregular grid covering 5 ha, with 14 transects varying from 200 to $240 \mathrm{~m}$, spaced 20-m from each other and 1000 to $1500 \mathrm{~m}$ above sea level. Sherman ${ }^{\circledR}$ live traps (100) baited with banana or manioc with peanut butter were set on the forest floor for four consecutive nights. Each trap site was recorded, and trapped animals were taken to a nearby station laboratory. Handling of small mammals was similar to the procedure used by Gettinger (1992). The animals were placed in plastic bags with cotton balls soaked with ethyl ether until they became unconscious, after which they were marked using an ear-code (Monteiro-Filho, 1987), weighed and sexed. The blood was collected by an incision in the tail made with a lancet and the animals were subsequently released at the same spot as the trap site. A voucher collection of skins and skulls of males and females of all collected host species were deposited at the Department of Ecology, State University of Rio de Janeiro. Mammal identification was based on morphological characters and cariotype, using material from the sacrificed specimens. Each trapping was carried out for four consecutive nights, totaling eight collections in each location, and the total trapping effort was 3200 traps/night/site.

The hemoparasite infection rates were determined by microscopic examination of Giemsa-stained blood smears. In this work, the blood parasite species were not determined.

Packed cell volumes (PCV) were determined when the collected amount of blood was enough to fill a heparinized microhematocrit capillary tube. In those cases after the reading, the capillary was broken just above the white globules and the plasma transferred to the refractometer and total plasma protein (TPP) was determined by refractometry, as recommended by Feldman et al. (2000).

Data on species, sex, weight, blood parasite frequency and trap site were recorded and stored for each host.
They were analyzed by the GLM procedure of the SAS (1987) software.

\section{Results}

A total of 374 rodents and 46 marsupials belonging to 15 species were collected. The rodents were represented by nine species: Akodon montensis (Thomas), Akodon serrensis (Thomas), Delomys dorsalis (Henzel), Delomys sublineatus (Thomas), Nectomys squamypes (Brants), Oligorysomys nigripes (Olfers), Oxymycterus sp (Watherhouse), Thaptomys nigrita (Lichtenstein), and Trynomis dimediadus (Günter). The six collected marsupial species were: Didelphis aurita (Wied-Neuwied), Gracilynanus sp (Burmeister), Marmosops incanus (Lund), Monodelphis scallops (Thomas), Philander frenata (Olfers), Thylamis velutinus (Wagner).

The frequency of each collected species whose red blood cells had parasites are presented in Table 1. A total of 65 specimens (15\%) belonging to 9 species (6 rodents and 3 marsupials) were infected with Hemobartonella $\mathrm{sp}$ and/or Babesia sp. Only one specimen of Akodon montensis showed Theileria sp in its lymphocytes.

The prevalence of parasitism was greater in rodents and for Hemobartonella sp. The five most abundantly collected rodent species, were: $O$. nigripes $(23.5 \%)$ followed by D. sublineatus (19\%), A. montensis (18\%), A. serrensis $(11.8 \%)$ and $D$. dorsalis $(8 \%)$. For the marsupials, the three most abundantly collected species were M. incanus (28.6\%), P. frenata (12.5\%) and T. velutinus $(10 \%)$. However Babesia sp was found only in the rodents $A$. montensis, $D$. sublineatus and $N$. squamypes.

The distribution of parasitism in the three studied areas and the body weight averages is presented in Table 2 . The greater prevalence occurred in Serra da Bocaina (Area II), with $47.7 \%$ of hemoparasitized specimens. There was no significant difference in body weight $(\mathrm{p}<0.01)$ among the studied species and hosts.

Packed cell volume (PCV) and the total plasma protein (TPP) for the specimens infected and non-infected by blood parasites are presented in Table 3 . There was no significant difference $(\mathrm{p}<0.01)$ among parasitized and non-parasitized specimens and among the study areas. Only 102 specimens from six species provided enough blood to fill the microhematocrit capillary tube in all specimens, and were included in the study: A. montensis, A. serrensis, D. dorsalis, D. sublineatus, O. nigripes and T. dimediadus.

\section{Discussion}

Direct microscopic identification of parasites in stained blood smears is confirmatory of their presence, but it is usually difficult to find the organisms in the parasitized animals. Therefore, despite the high specificity, microscopic examinations of blood smears are of low sensitivity for the detection of parasites in host animals. Serological methods, such as complement fixation tests and the indirect fluorescent antibody test are 
Table 1. Species, total number of slides, number of positive slides, percentage of each blood parasite regarding its host and percentage of males and females.

\begin{tabular}{|c|c|c|c|c|c|c|c|}
\hline \multirow[t]{2}{*}{ Specie } & \multirow{2}{*}{$\begin{array}{c}\text { Total } \\
\text { number } \\
\text { of slides }\end{array}$} & \multirow{2}{*}{$\begin{array}{c}\text { Number of } \\
\text { positive } \\
\text { Slides }\end{array}$} & \multicolumn{3}{|c|}{ Blood parasites (\%) } & \multirow{2}{*}{$\begin{array}{c}\text { Males } \\
(\%)\end{array}$} & \multirow{2}{*}{$\begin{array}{c}\text { Females } \\
(\%)\end{array}$} \\
\hline & & & Haemobartonella sp & $\begin{array}{c}\text { Babesia } \\
s p \\
\end{array}$ & $\begin{array}{c}\text { Theileria } \\
s p \\
\end{array}$ & & \\
\hline Akodon montensis & 172 & 31 & 90.6 & 6.3 & 3.1 & 38.7 & 33.3 \\
\hline Akodon serrensis & 76 & 09 & 100 & - & - & 66.7 & 33.3 \\
\hline Delomys dorsalis & 25 & 02 & 100 & - & - & 100 & - \\
\hline Delomys sublineatus & 42 & 08 & 75 & 25 & - & 87.5 & 12.5 \\
\hline Nectomys squamypes & 03 & 02 & 66.7 & 33.3 & - & - & 100 \\
\hline Oligorysomys nigripes & 34 & 08 & 100 & - & - & 75 & 25 \\
\hline Oxymiterus sp & 04 & - & - & - & - & 50 & 50 \\
\hline Thaptomys nigrita & 11 & - & - & - & - & 63.6 & 36.4 \\
\hline Trynomys dimediatus & 07 & - & - & - & - & 71.4 & 28.6 \\
\hline Gracilynanus $s p$ & 06 & - & - & - & - & 33.3 & 66.7 \\
\hline Marmosoptes incanus & 07 & 02 & 100 & - & - & 100 & - \\
\hline Monodelphis scalops & 03 & - & - & - & - & 100 & - \\
\hline Phylander frenata & 16 & 02 & 100 & - & - & 100 & - \\
\hline Thylamys velutinatus & 10 & 01 & - & - & - & 100 & - \\
\hline Didelphys aurita & 04 & - & - & - & - & 50 & 50 \\
\hline Total & 420 & 65 & - & - & - & - & - \\
\hline
\end{tabular}

Table 2. Species, number of positive slides, number of hosts in each mountain range and weight $(\mathrm{g})$ averages \pm standard deviation (s).

\begin{tabular}{lrccccc}
\hline \multicolumn{1}{c}{ Specie } & $\begin{array}{c}\text { Positive } \\
\text { slides }\end{array}$ & $\begin{array}{c}\text { Area I } \\
\text { Itatiaia }\end{array}$ & $\begin{array}{c}\text { Area II } \\
\text { Bocaina }\end{array}$ & $\begin{array}{c}\text { Area III } \\
\text { Fartura }\end{array}$ & $\begin{array}{c}\text { Weight } \\
\mathbf{g} \pm \mathbf{~ s}\end{array}$ & $\begin{array}{c}\text { Host Weight } \\
\mathbf{g} \pm \mathbf{~ s}\end{array}$ \\
\hline Akodon montensis & 31 & - & 19 & 12 & $0.367 \pm 0.078$ & $0.350 \pm 0.057$ \\
Akodon serrensis & 9 & 4 & 5 & - & $0.370 \pm 0.129$ & $0.373 \pm 0.012$ \\
Delomys dorsalis & 2 & - & 2 & - & $0.503 \pm 0.088$ & $0.505 \pm 0.008$ \\
Delomys sublineatus & 8 & - & 5 & 3 & $0.550 \pm 0.079$ & $0.560 \pm 0.097$ \\
Nectomys squamypes & 2 & 2 & - & - & $0.396^{\mathrm{a}}$ & $0.394^{\mathrm{a}}$ \\
Oligorysomys nigripes & 8 & - & - & 8 & $0.390 \pm 0.107$ & $0.385 \pm 0.089$ \\
Oxymiterus sp & - & - & - & - & $0.280^{\mathrm{a}}$ & - \\
Thaptomys nigrita & - & - & - & - & $0.430 \pm 0.098$ & - \\
Trynomys dimediadus & - & - & - & - & $0.384 \pm 0.089$ & - \\
Gracilyanus sp & - & - & - & - & $0.436 \pm 0.102$ & - \\
Marmosoptes incanus & 2 & 2 & - & - & $0.457 \pm 0.077$ & $0.445 \pm 0.103$ \\
Monodelphis scalops & - & - & - & - & $0.423^{\mathrm{a}}$ & - \\
Phylander frenata & 2 & - & - & 2 & $0.518 \pm 0.075$ & $0.521 \pm 0.072$ \\
Thylamys velutinatus & 1 & - & - & 1 & $0.397 \pm 0.082$ & $0.387^{\mathrm{a}}$ \\
Didelphis aurita & - & - & - & - & $0.355^{\mathrm{a}}$ & - \\
Total & 65 & 8 & 31 & 26 & & - \\
\hline
\end{tabular}

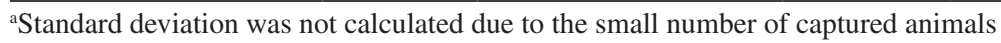

commonly used for detecting hemoparasite infections. However these tests can cause errors, because they are generally restricted to antibody detection, so a cross reactivity can occur (Baldani et al, 2004a). The protector immunity is not related with antibody levels, because the antibodies are produced against parasite-antigen and host-antigen, resulting in inflammatory reaction (Bittar et al., 2004). The enzyme-linked immunosorbent assay (ELISA) and several other techniques including in vitro cultures, DNA probes, polymerase chain reaction 
Table 3. Species, number of each analyzed specimen (n), Packed Cell Volume (PCV - \%) averages \pm sd (s) and Total Plasma Protein (TPP - g.dL $\mathrm{dL}^{-1}$ ) averages $\pm \mathrm{sd}(\mathrm{s})$ in each area and host.

\begin{tabular}{|c|c|c|c|c|c|c|c|c|c|}
\hline \multirow[t]{2}{*}{ Specie } & \multicolumn{3}{|c|}{ Area I-Itatiaia } & \multicolumn{2}{|c|}{ Area II-Bocaina } & \multicolumn{2}{|c|}{ Area III-Fartura } & \multicolumn{2}{|c|}{ Host } \\
\hline & $\mathbf{n}$ & PCV & TPP & PCV & TPP & PCV & TPP & PCV & TPP \\
\hline $\begin{array}{l}\text { Akodon } \\
\text { montensis }\end{array}$ & 47 & $47.50 \pm 6.8$ & $6.30 \pm 0.9$ & $43.70 \pm 5.5$ & $7.00 \pm 1.5$ & $47.70 \pm 3.76$ & $6.90 \pm 1.6$ & $45.8 \pm 5.2$ & $7.2 \pm 1.2$ \\
\hline $\begin{array}{l}\text { Akodon } \\
\text { serrensis }\end{array}$ & 28 & $42.50 \pm 6.5$ & $7.00 \pm 0.8$ & $55.00 \pm 5.8$ & $6.90 \pm 0.8$ & - & - & $48.0 \pm 4.3$ & $6.0 \pm 0.9$ \\
\hline $\begin{array}{l}\text { Delomys } \\
\text { dorsalis }\end{array}$ & 07 & $45.70 \pm 2.7$ & $6.40 \pm 1.1$ & $46.50 \pm 2.9$ & $7.50 \pm 0.9$ & - & - & $46.3^{a}$ & $6.8^{a}$ \\
\hline $\begin{array}{l}\text { Delomys } \\
\text { sublineatus }\end{array}$ & 13 & $42.70 \pm 4.5$ & $7.70 \pm 0.7$ & - & - & $48.50 \pm 4.4$ & $7.90 \pm 0.6$ & $44.3 \pm 4.9$ & $6.8^{a}$ \\
\hline Oligorisomys sp. & 03 & - & - & - & - & $47.50^{\mathrm{a}}$ & 7.10 & $50.0^{\mathrm{a}}$ & $7.0^{\mathrm{a}}$ \\
\hline $\begin{array}{l}\text { Trinomys } \\
\text { dimediatus }\end{array}$ & 04 & - & - & $56.00^{\mathrm{a}}$ & 6.50 & - & - & - & - \\
\hline Total & 102 & & & & & & & & \\
\hline
\end{tabular}

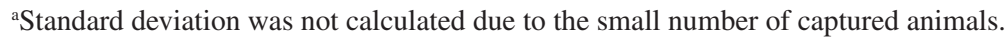

(PCR), nested polymerase chain reaction and western blot analysis, have been used for the diagnosis for blood parasites. However, except for serology, these methods are laborious, expensive and time-consuming (Baldani et al., 2004b). The presence of Haemobartonella sp and Babesia sp in the erythrocyte of rodents and marsupials from three mountain ranges in the Atlantic Forest in southeastern Brazil, showed that they are potentially hosts, so they can lead to an infection, transmitted by fleas and ticks, to domestic and wild animals, and men (Burato et al., 2004).

This work showed that the majority of hosts in all three areas had Haemobartonella sp (Table 1). A study of the associations between small mammals and fleas was undertaken in the same three areas where the present work was carried out. A total of 185 specimens belonging to 17 species (11 rodents and 6 marsupials) were parasitized by fleas. The rodent $A$. montensis was the host with the largest number of flea species collected (Moraes et al., 2003).

Haemobartonella muris can be found in the erythrocytes of mice, rats and hamsters. The clinical manifestations of this disease were observed when the animals presented immune suppression (Pereira, 2002).

Haemobartonella and Eperythrozoon species infecting dogs and cats have been reclassified as mycoplasmal parasites and are now known as Mycoplasma haemofelis (Ohio or large form of $\mathrm{H}$. felis), $M$. haemominutum (California or small form of $H$. felis), and H. haemocanis (H. canis) (Souza and Almosny, 2002; Messick, 2003).

Babesiosis is a tick-borne disease of domestic and wild animals and, rarely, of man (Madruga et al., 2002; Mendonça et al., 2003; Rios, 2003). From the blood smear examinations, 4 animals infected with Babesia sp (3 Akodon serrensis and 1 Delomys sublineatus, collected in Serra da Bocaina- Area II) were found, and in those specimens only nymphs of ixodid ticks were collected. In the Atlantic Rainforest (part of it) where our studies were undertaken, the invasion of domestic animals (cat- tle and equinus) is normal. Ixodid ticks can be infecting both hosts (Dall'Olio et al, 2001).

The occurrence of babesiosis from blood smear identification, was studied in 44 small rodents of six species captured in Silva Jardim and Nova Iguaçu municipalities, in the state of Rio de Janeiro, Brazil. The prevalence of infection was $27,3 \%$ in two species: Oligoryzomys nigripes and Rattus norvergicus. The other captured species were: Nectomys squamipes, Oryzomys angoya, Holochilus brasiliensis and Akodon cursor (Gazeta et al., 2004).

No information on the species studied in this work has been found in the literature, regarding the patterns of packed cell volume and total plasma protein. Nevertheless, some papers have proposed the standardization of those values for rodents used as lab animals. The packed cell volume (PCV) and total plasma protein (TTP) showed similar values to those of lab animals, such as hamsters, rats and mice (Moore, 2000ab).

Determination of packed cell volume is important to determine whether the captured specimens with blood parasites had decreased PCV, indicating anemia. High total plasma protein can indicate dehydration, and low, malnutrition, liver or kidney insufficiency. In this study, the specimens that had blood parasites were not anemic and neither had protein alterations, suggesting that the specimens are reservoirs of those parasites, which could be transmitted by ectoparasites such as fleas and ticks, to other mammals, including humans.

Acknowledgments - The Fundação de Amparo à Pesquisa do Estado de São Paulo (FAPESP) provided financial support (Process n. 99/101311-4 and 99/10844-2), and Ibama provided the collecting permits. To Adriano Dall'Olio and Marcos Ivo (UNIFEOB) for help during the fieldwork.

\section{References}

AB'SABER, AN., 1970. Províncias geológicas e domínios morfoclimáticos no Brasil. Boletim do CEPEGE, vol. 3, no. 1, p. 85-123. 
BALDANI ${ }^{\mathrm{a}}$ CD., FERRAZ, ART., NETO, AQ. and MACHADO, RZ., 2004.Estudo comparativo de técnicas diretas no diagnóstico de Babesia equi em eqüinos naturalmente infectados e submetidos a treinamento físico de intensidade progressiva. Rev Bras Parasitol Vet, vol. 13, suplemento no. 1, p. 231.

BALDANI $^{\mathrm{b}}$, CD., MACHADO, RZ., BOTTEON, PTL., TAKAKURA, FS.and MASSARD, CL., 2004. An enzymelinked immunosorbent assay for the detection of $\mathrm{IgG}$ antibodies against Babesia equi in horses. Cienc Rural, vol. 34, no. 5, p. $1525-1529$.

BARREIRA, JD., DORIA ROSSI, MI., SILVA, GVO., PIRES, FA. and MASSARD, CL., 2004. Avaliação clinico-parasitológica de Meriones unguilatus frente à infecção experimental com amostras modificadas de Babesia bovis e B.bigemina. Rev Bras Parasitol Vet, vol. 13, suplemento no. 1, p. 230

BITTAR, JFF., RIBEIRO, MFB., MARCIANO, APV., SALCEDO, JHP., MARTINS-FILHO, OA. 2004. Perfil fenotípico de linfócitos periféricos de bovinos de raças européias. Arq Bras Med Vet Zootec, vol. 56, p. 107-110.

BOSSI, DEP., LINHARES, AX. and BERGALLO, HG., 2002. Parasitic arthropods of some wild rodents from JuréiaItatins Ecological Station, state of São Paulo, Brazil. Mem Inst Oswaldo Cruz, vol. 97, no. 7, p. 959-963.

BURATO, AC., BELO, NO., SILVEIRA, JAG., MOREIRA, SM., BASTOS, CV. and PASSOS, LMF., 2004. Hemobartonelose felina: aspectos epidemiológicos, clínicos e hematológicos. Rev Bras Parasitol Vet, vol. 13, suplemento no. 1, p. 241.

DALL'OLIO, AJ., RONCONI, A., BOSSI, DEP. and SILVA, MAML. September, 2001. Ixodid ticks vectors of babesiosis to rodents of brazilian rain Forest. Third International Congress of Vector Ecology. Barcelona, Spain, 16/21 de Setembro, p. 18.

DASZAK, P.; CUNNINGHAM, AA. and HYATT, AD., 2000. Emerging infectious diseases of wildlife-threats to biodiversity and human health. Science, vol. 287, no. 5452, p. 443-449.

-, 2001.Anthropogenic environmental change and the emergence of infectious diseases in wildlife. Acta Trop, vol. 78, no. 2, p. 103-116.

FELDMAN, BF., ZINCKL, JG. and JAIN, NC., 2000. Schalm's Veterinary Hematology. $5^{\text {th }}$ ed., Lippincott Williams \& Wilkins, Philadelphia. p. 1111-1119.

GAZETA, GS., CARVALHO, RW., AVELAR, RF., AMORIM, M. and ABOUD-DUTRA, AE., 2004. Ocorrência de Babesia sp em pequenos roedores no Brasil. Arq Bras Med Vet Zootecn, vol. 56 , no. 6 , p. 741-744.

GETTINGER, D., 1992. Host specificit of Laelaps (Acari: Laelapidae) in Central Brazil. J Med Entomol, vol. 29, no. 1, p. 71-77.
MADRUGA, CR., LEAL, CRB. and FERREIRA, AMT. et al., 2002. Análise genética e antigênica de isolados de Babesia bigemina das cinco regiões fisiográficas do Brasil.Pesq Vet Bras, vol. 22, no. 4, p. 153-160.

MENDONÇA, CL., VIEIRA, D. and KOHAYAGAWA, A., 2003. Avaliação clínica e hematológica em bezerros Nelore infectados experimentalmente com isolados de Babesia bigemina das regiões Sudeste, Nordeste e Norte do Brasil. Pesq Vet Bras, vol. 23, no. 2, p. 52-60.

MESSICK, JB., 2003. New perspectives about Hemotrophic mycoplasma (formerly, Haemobartonella and Eperythrozoon species) infections in dogs and cats. Vet Clin North Am Small Anim Practice, vol. 33, no. 1, p. 1453-1465.

MONTEIRO FILHO, ELA., 1987. Biologia Reprodutiva $e$ Espaço Domiciliar de Didelphis albiventris em uma Área Perturbada na Região de Campinas, Estado de São Paulo, MSc Thesis, State University of Campinas, Brazil.

MOORE, DM., 2000. Hematology of Mongolian gerbil e Syrian (golden) Hamster. In, Feldman, BF., Zinckl, JG. and Jain, NC. Schalm's Veterinary Hematology. $5^{\text {th }}$ ed. Lippincott Williams \& Wilkins, Philadelphia. p. 1111-1119.

-. Hematology of rat and mouse. In, FELDMAN, BF., ZINCKL, JG., and JAIN, NC. Schalm's Veterinary Hematology. $5^{\text {th }}$ ed. Lippincott Williams \& Wilkins, Philadelphia. p. 1210-1224.

MORAES, LB., BOSSI, DEP. and LINHARES, AX., 2003. Siphonaptera parasites of wild rodents and marsupials trapped in three mountain ranges of the Atlantic Forest in Southeastern Brazil. Mem Inst Oswaldo Cruz, vol. 98, no. 8, p. 1071-1076.

PEREIRA, AM., 2002. Principais doenças dos camundongos, ratos e hamsters. In, Andrade, A. et al. Animais de Laboratório - criação e experimentação. Editora Fiocruz, Rio de Janeiro. p. $105-137$.

QUINTÃO-SILVA, MG. and RIBEIRO, MFB., 2003. Infection rate of Babesia spp sporokinetes in engorged Boophilus microplus from na area of enzootic stability in the state of Minas Gerais, Brazil. Mem Inst Oswaldo Cruz, vol. 98, no. 8, p. 999-1002.

RIOS, L., ALVAREZ, G. and BLAIR, S., 2003. Serological and parasitological study and report of first case human babesiosis in Colombia. Rev Soc Bras Med Trop, vol. 36, no. 4, p. 493-498.

SAS Institute, Inc., 1987. S.A.S. Users Guide: Statistic. Vesion $6^{\text {th }}$ ed. Caru, n.c., E.U.A.

SOUZA, AM. and ALMOSNY, NRP., 2002. Hemobartonelose em pequenos animais domésticos e como zoonose. In, Almosny, NRP. Hemoparasitoses em pequenos animais domésticos e como zoonose. L.F.Livros, Rio de Janeiro. p. 89-109. 
